\title{
Managing agricultural soils of Pakistan for food and climate
}

\author{
Rattan Lal \\ President, International Union of Soil Sciences (IUSS) Carbon Management and Sequestration Center, \\ The Ohio State University Columbus, OH 43210 USA
}

\begin{abstract}
Pakistan; a predominantly arid land region; has a large, growing, urbanizing and increasingly affluent population. Soil and water resources are finite, with per capita arable land area of 0.10 ha by 2050, and prone to degradation by inappropriate management, harsh environments and changing climate. Nonetheless, agriculture productivity increased strongly between 1960 and 2016. Whereas, the population of Pakistan increased by a factor of 4.5 between 1960 and 2018 (from 45 to 201 million), total cereal grain production increased by a factor of 6.5 (from 6.6 to 43.0 million ton). Despite the impressive gains in agricultural production since the Green Revolution era, there is no cause for complacency because even greater challenges lie ahead. Total food production may have to be doubled between 2015 and 2050 because of the growth in population along with rapidly urbanizing and increasingly affluent lifestyle. The national agronomic crop yield $(2.8 \mathrm{Mg} / \mathrm{ha}$ for wheat, $3.8 \mathrm{Mg} / \mathrm{ha}$ for rice, and $4.6 \mathrm{Mg} / \mathrm{ha}$ for maize) may have to be increased drastically, and that too in a changing and uncertain climate. Important among the challenges are the growing incidence of drought stress and heatwave, and increasing risks of soil degradation and desertification. Further, soil resources must also be managed to advance the Sustainable Development Goals (SDGs) of the UN; achieve Land Degradation Neutrality proposed by the UNCCD; implement the "4 per Thousand" program of soil carbon sequestration initiated at COP21 in Paris in 2015; and fulfil the aspirations of better lifestyle for the people of Pakistan. The strategy is to restore degraded soils and desertified ecosystems through sustainable intensification. The goal is to produce more from less by reducing losses (i.e., water, nutrients, soil) and enhancing eco-efficiency of inputs (i.e., fertilizer, irrigation water, energy). Vertical increase in agronomic yield, by restoring soil health and adopting best management practices (BMPs), is the only viable option because there is no scope for any horizontal expansion. Site/regional specific BMPs may include conservation agriculture along with retention of crop residue mulch and without any in-field burning of biomass; incorporation of a cover crop (forages) in the rotation cycle; and use of integrated nutrient management (INM) involving a judicious combination of organic (compost, manure, biofertilizers) and inorganic sources of nutrients, and integration of crops with livestock and trees. Further, the flood irrigation must be replaced by drip sub-irrigation system. Chosen BMPs must create a positive soil ecosystem $C$ budget, and restore the soil organic carbon stock.
\end{abstract}

\section{Introduction}

Pakistan is a predominantly dryland country: $80 \%$ of its land area is arid and semi-arid, $12 \%$ sub-humid, and $8 \%$ under humid climate (Khan et al., 2012). Thus, soils of arid and semi-arid regions are vulnerable to a wide range of degradation processes. As is the case in arid and semi-arid climates elsewhere in south-central/southern Asia and SubSaharan Africa; drought stress, salinization, accelerated soil erosion, and depletion of soil fertility and soil organic matter (SOM) content are among the major causes of soil degradation and desertification, and of moderate agronomic productivity and low use efficiency of inputs. Thus, understanding the climate-soil-productivity nexus is pertinent to meeting the food and nutritional demands of the growing population.

The population of Pakistan increased from about 30 million in 1947 to 201 million in 2018, and is projected to be 244 million in 2030, 307 million in 2050 and 352 million in 2100 (Table 1). Fortunately, the present rate of growth of about $2.0 \% / \mathrm{yr}$ is on a declining trend and is projected to reach $0.3 \% / y r$ by 2100 (Table 2). Growth in human population, reflected by a rapid increase in population of some cities (Table 3), is an indication of the strong urbanization trend in Pakistan. Between 1950 and 2030, the urban population will increase by a factor of 23.4 in Karachi, 15.5 in Lahore, 16.6 in Rawalpindi, 15.1 in Multan, 31.9 in Faisalabad, and 31.8 in Gujranwala (Table $3)$. The proportion of urban population has increased steadily from $22.4 \%$ in 1960 to $39.7 \%$ in 2018 (Table 1) and is projected to exceed $50 \%$ by 2050 (Table 2). In accord with the growth in human population, the population of livestock has also increased from a total of 40.5 million in 1961 to 180.5 million in 2016, by a factor of 4.5 (Table 4). Relatively large increase in population of buffalo, cattle, goats, and sheep may have notable impacts on land use and

*Email: 1al.1@osu.edu 
Table 1: Population dynamics in Pakistan (adapted from UN, 2017; World Bank, 2018)

\begin{tabular}{lcccccccccc}
\hline Parameter & Units & $\mathbf{1 9 5 0}$ & $\mathbf{1 9 6 0}$ & $\mathbf{1 9 8 3}$ & $\mathbf{1 9 9 0}$ & $\mathbf{2 0 0 0}$ & $\mathbf{2 0 0 8}$ & $\mathbf{2 0 1 0}$ & $\mathbf{2 0 1 5}$ & $\mathbf{2 0 1 8}$ \\
\hline Total population & $10^{6}$ & 38 & 45 & 86 & 108 & 139 & 164 & 171 & 189 & 201 \\
Population & Person $/ \mathrm{km}^{2}$ & 49 & 58 & 112 & 140 & 180 & 212 & 221 & 246 & 261 \\
Population growth & $\% / \mathrm{yr}$ & 1.15 & 2.32 & 3.42 & 2.95 & 2.3 & 2.06 & 2.1 & 2.07 & 2.0 \\
Urban population & $\%$ of total & - & 22.4 & 29.6 & 31.5 & 34.4 & 36.6 & 37.2 & 38.5 & 39.1 \\
\hline
\end{tabular}

Table 2: Projected population of Pakistan (recalculated from UN, 2017)

\begin{tabular}{lcccccc}
\hline Parameter & Units & $\mathbf{2 0 1 7}$ & $\mathbf{2 0 2 0}$ & $\mathbf{2 0 3 0}$ & $\mathbf{2 0 5 0}$ & $\mathbf{2 1 0 0}$ \\
\hline Population & $10^{6}$ & 197 & 208 & 244 & 307 & 352 \\
Density & Persons $/ \mathrm{km}^{2}$ & 259 & 270 & 317 & 398 & 457 \\
Rate of growth & $\% / \mathrm{yr}$ & 2.0 & 1.93 & 1.50 & 0.93 & 0.30 \\
Median age & $\mathrm{yr}$ & - & 23.5 & 25.6 & 30.9 & - \\
Urban & $\%$ & 39.0 & 40.2 & 44.2 & 50.7 & - \\
\hline
\end{tabular}

Table 3: Growth of some urban cities in Pakistan (UN, 2014)

\begin{tabular}{lccrrrr}
\hline & \multicolumn{5}{c}{ Population (Million) } \\
\cline { 2 - 6 } City & $\mathbf{1 9 5 0}$ & $\mathbf{2 0 0 0}$ & $\mathbf{2 0 1 0}$ & $\mathbf{2 0 2 5}$ & $\mathbf{2 0 3 0}$ & Factor \\
\hline Karachi & 1.06 & 10.03 & 14.1 & 22.0 & 24.8 & 23.4 \\
Lahore & 0.84 & 5.45 & 7.5 & 11.50 & 13.0 & 15.5 \\
Rawalpindi & 0.23 & 1.52 & 2.1 & 3.34 & 3.81 & 16.6 \\
Multan & 0.19 & 1.26 & 1.7 & 2.51 & 2.87 & 15.1 \\
Faisalabad & 0.17 & 2.14 & 3.0 & 4.78 & 5.42 & 31.9 \\
Gujranwala & 0.12 & 1.23 & & 2.87 & 3.81 & 31.8 \\
\hline
\end{tabular}

Table 4: Cattle population in Pakistan (FAO, 2018)

\begin{tabular}{|c|c|c|c|c|c|c|}
\hline \multirow[b]{2}{*}{ Year } & \multicolumn{6}{|c|}{ Million } \\
\hline & Buffalo & Camel & Cattle & Goats & Sheep & Total \\
\hline 1961 & 6.7 & 0.6 & 14.2 & 8.8 & 10.2 & 40.5 \\
\hline 1970 & 9.3 & 0.7 & 14.6 & 13.2 & 13.1 & 50.9 \\
\hline 1980 & 11.5 & 0.8 & 14.8 & 25.0 & 21.4 & 73.5 \\
\hline 1990 & 17.4 & 1.0 & 17.7 & 35.4 & 25.7 & 97.2 \\
\hline 2000 & 22.7 & 0.8 & 22.0 & 47.4 & 24.1 & 117.0 \\
\hline 2010 & 29.4 & 1.0 & 34.3 & 59.9 & 27.8 & 152.4 \\
\hline 2016 & 36.6 & 1.0 & 42.8 & 70.3 & 29.8 & 180.5 \\
\hline Factor of increase & 5.5 & 1.7 & 3.0 & 8.0 & 2.9 & 4.5 \\
\hline
\end{tabular}

Table 5: Per capita energy use in Pakistan (recalculated from World Bank, 2018)

\begin{tabular}{llllll}
\hline Parameter & Units & $\mathbf{1 9 9 0}$ & $\mathbf{2 0 0 0}$ & $\mathbf{2 0 0 8}$ & $\mathbf{2 0 1 0}$ \\
\hline Energy use & $\mathrm{Kg}(\mathrm{oe})$ & 398.4 & 462.5 & 504.6 & 498.5 \\
$\mathrm{CO}_{2}$ emissions & $\mathrm{Mg}$ & 0.64 & 0.77 & 0.97 & 0.95 \\
\hline
\end{tabular}

Table 6: Total and per capita food grain production in Pakistan (recalculated from FAO, 2018; UN, 2017)

\begin{tabular}{cccc}
\hline Year & $\begin{array}{c}\text { Total Production } \\
\left(\mathbf{1 0}^{\mathbf{6}} \mathbf{M g}\right)\end{array}$ & $\begin{array}{c}\text { Population } \\
\left(\mathbf{1 0}^{\mathbf{6}}\right)\end{array}$ & $\begin{array}{c}\text { Production } \\
(\mathbf{k g} / \mathbf{p e r s o n})\end{array}$ \\
1961 & 6.6 & 46.0 & 143 \\
1970 & 12.0 & 58.1 & 207 \\
1980 & 17.0 & 78.1 & 218 \\
1990 & 20.8 & 104.6 & 199 \\
2000 & 30.3 & 138.5 & 219 \\
2010 & 34.7 & 170.6 & 203 \\
2015 & 41.0 & 189.4 & 216 \\
2016 & 43.0 & 193.2 & 223 \\
\hline Increase since 1961 & 6.52 & 4.20 & 1.52 \\
\hline
\end{tabular}


soil quality. Whereas the per capita energy use remains to be low, there is a distinct trend of increase in energy demand (Table 5), with consequences to emission of greenhouse gases.

Whereas the population of Pakistan increased by a factor of 4.5 between 1960 and 2018 (from 45 to 201 million), total cereal grain production (rice, wheat, sorghum, millet, maize) increased by a factor of 6.5 from 6.6 to 43.0 million metric ton (Table 6). Thus, the per capita cereal grain production increased strongly between 1961 and 1980, but has stayed constant between 1980 and 2016 at about $220 \mathrm{~kg} /$ person (Table 6). Despite the impressive gains, there is no cause for complacency because even bigger challenges lie ahead. Not only is the population projected to $\sim$ double (increase by a factor of 1.8 ) between now and the year 2100 (from 200 to 352 million), dietary preferences may also shift towards more animal-based products because of the increasing affluence and the overall economic prosperity. The challenge of advancing food and nutritional security is also aggravated by the everincreasing risks of soil degradation, growing urbanization, the changing climate, and dwindling aquifers.

Therefore, the objective of this article is to discuss the challenges and opportunities of sustainably managing soil resources in a changing and uncertain climate, and deliberating the concept of sustainable intensification of agroecosystems.
However, the land area equipped for irrigation has followed an increasing trend from 10.8 Mha in 1961 to 15.7 Mha in 1990, and 20.2 Mha in 2015. Any future increase in irrigation may be a challenging task because of the limited water resources. Whereas the land area under permanent crops has followed a trend of modest increase between 1990 and 2010 (from 0.46 to 0.81 Mha), there has been a steady decline in the area under forest, which decreased from 2.53 Mha in 1990 to 1.47 Mha in 2015, at an average annual rate of $2.8 \% / \mathrm{yr}$ (Table 7 ).

The impact of increase in human population is vividly indicated by decrease in the per capita land resources in Pakistan (Table 8). The total per capita land area (ha/person) for 1950, 2015, 2030, 2050, and 2100, respectively, is estimated at $0.95,0.18,0.15,0.12$, and 0.10 for agricultural land; $0.82,0.15,0.12,0.10$, and 0.09 for arable land; $0.29,0.10,0.08,0.067$, and 0.057 for irrigated land; and $0.13,0.025,0.02,0.015$, and 0.014 for pasture land. By 2050, the basic necessities of life must be met and wellbeing of people realized from a meagre per capita land area of 0.10 ha of cropland, 0.07 ha of irrigated land and 0.015 of pasture land. This is the challenge for researchers, farmers, land managers, policymakers, and the general public.

Not only is the per capita land area low, its productivity is also vulnerable to a severe decline because of degradation of soil (i.e., decline in soil structure, erosion,

Table 7: Land use in Pakistan (FAO, 2018; World Bank, 2018)

\begin{tabular}{lrrrrrrrc}
\hline & \multicolumn{9}{c}{ Mha } \\
\cline { 2 - 8 } Land use & $\mathbf{1 9 6 1}$ & $\mathbf{1 9 7 0}$ & $\mathbf{1 9 8 0}$ & $\mathbf{1 9 9 0}$ & $\mathbf{2 0 0 0}$ & $\mathbf{2 0 1 0}$ & $\mathbf{2 0 1 5}$ & \% Change \\
\hline Agricultural land & 35.7 & 35.9 & 37.4 & 35.2 & 36.7 & 35.2 & 36.3 \\
Arable land & 30.6 & 30.7 & 32.1 & 29.8 & 31.0 & 29.4 & 30.4 \\
Permanent crops & 0.15 & 0.17 & 0.31 & 0.46 & 0.66 & 0.85 & 0.81 & -0.01 \\
Irrigated land & 10.8 & 13.0 & 14.7 & 15.7 & 18.1 & 20.2 & 20.2 & 187 \\
Pastures & 5.0 & 5.0 & 5.0 & 5.0 & 5.0 & 5.0 & 5.0 & 0 \\
Forest & - & - & - & 2.5 & 2.1 & 1.7 & 1.5 & -40 \\
\hline
\end{tabular}

Table 8: Per capita land resources in Pakistan

\begin{tabular}{llllll}
\hline & \multicolumn{7}{c}{ Mha } & $\mathbf{2 0 5 0}$ \\
\cline { 2 - 6 } Land use & $\mathbf{1 9 5 0}$ & $\mathbf{2 0 1 5}$ & $\mathbf{2 0 3 0}$ & $\mathbf{2 0 5 0}$ & $\mathbf{2 1 0 0}$ \\
\hline Agricultural land & 0.95 & 0.18 & 0.15 & 0.12 & 0.10 \\
Arable land & 0.82 & 0.15 & 0.12 & 0.10 & 0.09 \\
Irrigated land & 0.29 & 0.10 & 0.08 & 0.067 & 0.057 \\
Pasture land & 0.13 & 0.025 & 0.02 & 0.015 & 0.014 \\
\hline
\end{tabular}

\section{Land Use and Agronomic Yields in Pakistan}

Because of the predominately arid and semi-arid climate, agricultural land resources of Pakistan are finite. Therefore, the agricultural land area has been constant since 1990 at about 30 million hectare (Mha) for arable land and 5 Mha for permanent pastures and meadows (Tables 7). salinization, depletion of soil organic matter/ SOM and nutrient contents) and the projected climate change especially by the drought stress. Furthermore, conversion of agriculture to other land uses (i.e., urbanization, infrastructure development, recreation) must also be considered. 


\section{Soil Degradation in Pakistan}

Soil degradation and desertification, serious problems because of the harsh climate and fragile soils managed by resource-poor and small land holders, may be aggravated by the growing pressure of the human population and by the changing and uncertain climate characterized by increase in frequency of extreme events (i.e., the drought-flood syndrome, heatwave). Yet, the problems of aridization and desertification have plagued the region ever since the collapse of the Mohenjo-Daro/Harappan civilization. The first urban civilization of the world, of about 5 million people, was a Bronze Age Civilization (3300-1300 BCE) and had the mature period of 2600-1900 BCE. The civilization extended from the present day northeast Afghanistan to Pakistan and northwest India. Agricultural/farming settlements began around 4000 BCE (Conningham and Young, 2015; Kenoyer, 1991). This flourishing civilization collapsed presumably because of the climate change about 2000 BCE. This era was characterized by an abrupt decline in the rainfall, change in the course of
Mha affected by salinization, 2.0 Mha are in the canal command area (Corbishley and Pearce, 2007). Risks of salinization are aggravated by flood-based excessive irrigation with a poor quality and brackish water (Condom et al., 1999; Shafqat et al., 2016; Qureshi et al., 2004). Estimates of the area affected by salinization may be more reliable because these can be assessed by the use of remote sensing techniques (Khan et al., 2005; Abbas and Khan, 2007; Iqbal, 2011). However, reclamation of saline/sodic soils necessitate leaching with a good quality irrigation water in conjunction with the use of gypsum-based amendments (Ahmad et al., 2015). However, estimates of the soil degradation using geo-information technology can be more reliable (Ahmad, 2013). Deforestation is and has been an important cause of soil erosion, especially in the hilly region.

The issue of the severity of desertification in Pakistan cannot be over-emphasized (Mian and Javed, 1989; Anjum et al., 2010; Khan et al., 2015), especially that of the rangelands in arid and semi-arid regions (Ahmad et al.,

Table 9: Estimates of soil degradation in Pakistan

\begin{tabular}{|c|c|c|c|c|c|c|c|c|c|c|}
\hline \multirow[b]{2}{*}{$\begin{array}{c}\text { Type of } \\
\text { Degradation }\end{array}$} & \multicolumn{2}{|c|}{$\begin{array}{c}\text { FAO } \\
(1994)\end{array}$} & \multicolumn{2}{|c|}{$\begin{array}{l}\text { Van Lynden and } \\
\text { Oldeman (1997) }\end{array}$} & \multicolumn{2}{|c|}{$\begin{array}{l}\text { Tariq et al. } \\
(2004)\end{array}$} & \multicolumn{2}{|c|}{$\begin{array}{l}\text { Shah and Arshad } \\
\qquad(2006)\end{array}$} & \multicolumn{2}{|c|}{$\begin{array}{c}\text { Khan et al. } \\
(\text { (2012) }\end{array}$} \\
\hline & Mha & $\begin{array}{l}\% \text { of total } \\
\text { land area }\end{array}$ & Mha & $\begin{array}{l}\% \text { of total } \\
\text { land area }\end{array}$ & Mha & $\begin{array}{c}\% \text { of } \\
\text { total land } \\
\text { area }\end{array}$ & Mha & $\begin{array}{l}\% \text { of total } \\
\text { land area }\end{array}$ & Mha & $\begin{array}{l}\% \text { of total } \\
\text { land area }\end{array}$ \\
\hline Water erosion & 7.2 & 9.0 & 21.2 & 26.6 & 11.0 & 13.8 & 13.1 & 16.5 & 11.0 & 13.8 \\
\hline Wind erosion & 10.7 & 13.4 & 14.4 & 18.0 & 3.5 & 4.4 & 6.2 & 7.8 & 3.5 & 4.4 \\
\hline Water logging & 1.0 & 1.3 & 14.3 & 17.9 & - & - & 1.6 & 2.0 & 11.0 & 13.8 \\
\hline Salinization & 4.2 & 5.3 & - & - & 5.7 & 7.2 & 6.3 & 7.9 & 5.3 & 6.7 \\
\hline Deforestation & 0.08 & 0.05 & - & - & - & - & - & - & 0.05 & 3.1 \\
\hline $\begin{array}{l}\text { Soil fertility } \\
\text { decline }\end{array}$ & 5.2 & 6.5 & 27.7 & 34.7 & - & - & 30.0 & 37.6 & - & - \\
\hline
\end{tabular}

Ghaggar-Harka river, and an overall desertification of the ecosystems. The land area of the city of Mohenjo-Daro declined from 85 ha to 3 ha between 1800 and 1700 BCE. However, the problem of soil and environmental degradation has persisted even during the $20^{\text {th }}$ and the $21^{\text {st }}$ century, and is regrettable being exacerbated.

Severity of soil erosion in the Punjab province was reported by Harold Glover (1941), and the problem has since been aggravated (Khan et al., 2012). Regardless of the severity of the problem, estimates of land area (Mha) affected by different processes of soil degradation in Pakistan are highly variable (Table 9), and range from 7.2 to 21.2 for water erosion, 3.5 to 14.4 for wind erosion, 1.0 to 14.3 for waterlogging, and 4.2 to 6.3 for salinization. It is widely argued that 16 Mha of land area in Pakistan is affected by soil erosion, of which 11.2 Mha is vulnerable to water erosion (Daily Times, 19 November 2016). Of the 5.8
2012). Uncontrolled grazing at an excessive rate aggravates degradation of rangelands (Qasim et al., 2017; Gul et al., 2016). In general, soil degradation is caused and perpetuated by an unsustainable land use (Ali et al., 2017; Zokaib and Naser, 2011).

\section{Adverse Impacts of Soil Degradation}

Soil degradation has strong adverse effects on the humanity and the environment. "Health of soil, plants, animals, people and ecosystems is one and indivisible" so said Sir Albert Howard in his presidential address to the Indian Science Congress in 1926 (Howard, 1925; Howard and Howard, 1929). Indeed, degradation of soil leads to decline in food and nutritional security, reduction in renewability and quality of water resources, decrease in quality and composition of air, and reduction in activity and species diversity of soil biota - macro, meso, and micro (Fig.1). There is a strong soil-environment-human nexus. 
Thus, restoration of degraded soils and desertified ecosystems is critical to human wellbeing and nature conservancy, especially in densely populated Pakistan with finite arable land, limited water resources, and harsh arid/semi-arid climate. Yes, restoring degraded soil must be the highest priority and of an utmost importance and urgency. one hand, and policymakers, farming community and the general public on the other.

There is a strong poverty-soil degradation nexus (Qiu et al., 2017). Therefore, poverty alleviation of rural communities necessitates adoption of site-specific BMPs for improving production. In addition to understanding the biophysical process of soil degradation, it is also pertinent

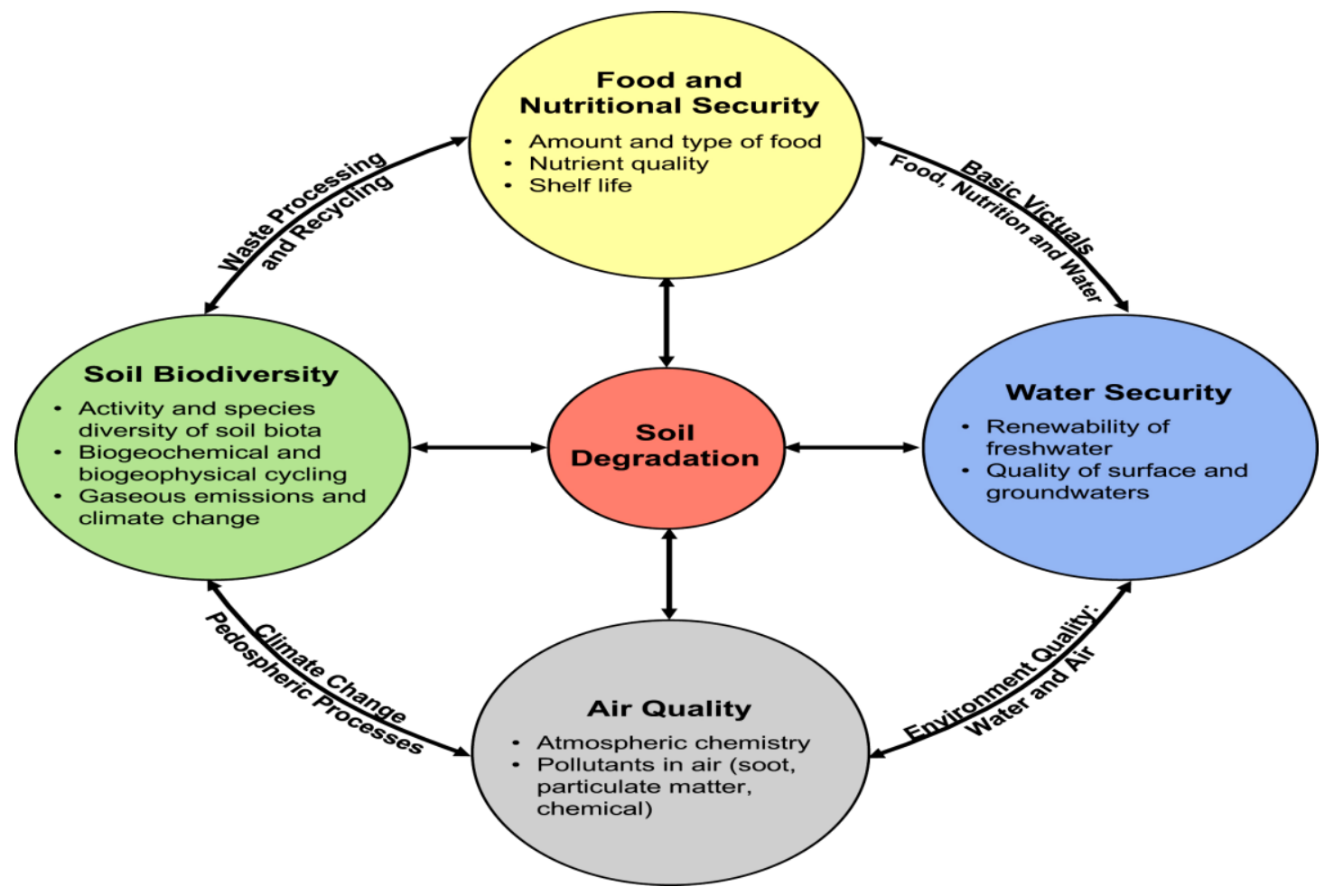

\section{Soil Restoration}

Restoring degraded soil must be the engine of economic development and rural prosperity in Pakistan and elsewhere in South Asia. Restoration of degraded soils and desertified ecosystems is also of interest to several international organizations. For example, the UN Convention to Combat Desertification (UNCCD) has adopted a program on Land Degradation Neutrality (LDN) with the objective to maintain or enhance the natural capital and the related ecosystem services (Cowie et al., 2018). The "4 per Thousand" program adopted at COP21 in Paris in 2015 is aimed at sequestration of soil organic carbon (SOC) at the rate of $0.4 \%$ per year to $40-\mathrm{cm}$ depth to mitigate climate and advance food security (Chambers et al., 2016; Lal, 2016; Minasny et al., 2017). Similarly Adapting African Agriculture (AAA) was initiated in Marrakech at COP22 in 2016 (Lal, 2018). Towards the need to translate science into action, there must be a mechanism for a continuous dialogue between scientific community on the to understand the farmers' perception of soil degradation and to evaluate the socioeconomic determinants (Qasim et al., 2011). Involvement of farmers and land managers in the process of improving multi-dimensional sustainability and for identifying site-specific conditions for sustainable agricultural development (Zulfiqar et al., 2017).

In addition to mapping degraded soils at a scale of $1: 10,000$, it is also important to identify critical soil properties and establish their threshold value. There is a need to develop and use appropriate soil quality indices (SQI) in relation to agronomic productivity and other ecosystem services. For example, critical level of SOC content in the root zone is considered to be $\sim 2 \%$ (Loveland and Webb, 2003). Similarly, identification of critical level is also essential for key parameters including soil bulk density, topsoil depth, available water holding capacity, penetrometer resistance, aggregation, $\mathrm{p}^{\mathrm{H}}$, electrical conductivity, cation exchange capacity, nutrient reserves etc. Improving and sustaining soil health is a key 
determinant of agronomic productivity and nature conservancy. For the rice-wheat system in Punjab, Pakistan, Iqbal et al. (2014) observed that a pertinent SQI is based on soil bulk density, plant available water capacity, aggregate stability, SOC content, microbial biomass-C, mineralizable $\mathrm{N}, \mathrm{p}^{\mathrm{H}}$ and CEC.

\section{Soil Management for Sustainable Intensification}

The SOC concentration in most soils of the Indus Plains and elsewhere in Pakistan is low at about $0.5 \%$ and often as low as $0.1 \%$ in the root zone. The low SOC concentration affects agronomic productivity and use efficiency of input (Lal, 2014), especially for the rice-wheat and other farming systems in Pakistan. However, the SOC concentration can be restored by adoption of the best management practices (BMPs). The strategy is to create a positive soil/ecosystem $\mathrm{C}$ budget by increasing the input of biomass- $\mathrm{C}$ to more than the losses by decomposition and erosion. Therefore, site-specific BMPs include conservation agriculture (CA), residue retention as mulch, use of integrated nutrient-management (INM) involving input of manure/compost use of biochar (Rasul et al., 2017) and integration of crops with livestock and trees. The experimental data from several studies indicate the beneficial impact of $\mathrm{CA}$ on SOC sequestration. Based on field experiments conducted in Faisalabad, Ali et al. (2013) evaluated the potential of SOC sequestration from 600 to $945 \mathrm{~kg} \mathrm{C} / \mathrm{ha} . \mathrm{yr}$.

Some examples of adoption of soil restoration projects in different regions of Pakistan comprise the Farm Forestry Support Project (FFSP) (Khan et al., 2009), the modified hydrological approach in conjunction with chemical and biological measures to reclaim salt-affected soils (Irshad et al., 2007); and the People and Resource Dynamic Project (PARDYP) in the Hindu Kush region (Allen, 2001).

\section{Advancing Food and Nutritional Security While Restoring the Environment}

An impressive increase in total food crop production in Pakistan by a factor of 6.5 between 1961 and 2016 (Table 6 ) is attributed to adoption of improved varieties, increase in land area under irrigation, and input of chemical fertilizers. Similar to the increase in land area equipped for irrigation from 10.8 Mha in 1961 to 20.2 Mha in 2015 by $187 \%$ (Table 7), there was also a drastic increase in the use of chemical fertilizers (Table 10). For example, fertilizer consumption between 1961 and 2002 increased from 41.7 thousand ton to 2.34 million ton for nitrogenous and 42.1 thousand ton to 2.96 million ton for total use of chemical fertilizers (Table 10; FAO, 2018). The data show a preferential application of $\mathrm{N}$ compared with that of $\mathrm{P}$ and $\mathrm{K}$

Table 10: Fertilizer use in Pakistan (adapted from FAO, 2018)

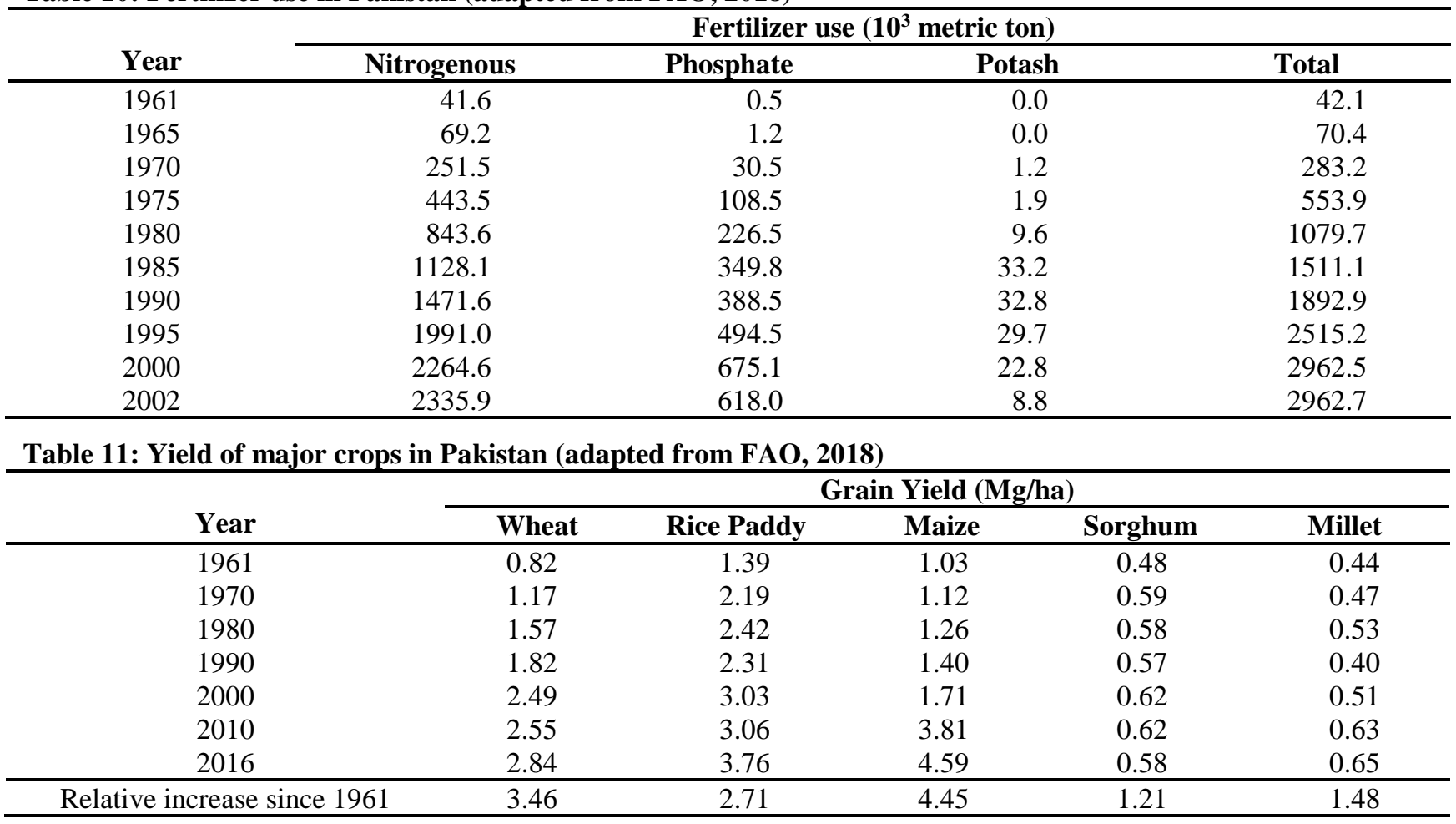


(and other micronutrients) which can lead to elemental imbalance. The data in Figure 2 show a linear increase in the rate of fertilizer use in cropland $(2.6 \mathrm{~kg} / \mathrm{ha} . \mathrm{yr})$ between 2002 and 2015. Consequently, there has been a strong increase in grain yield of major cereals including rice, wheat, and maize. However, there was a little if any increase in the yield of sorghum and millet, probably because these crops are grown under rainfed conditions.

Alas, increase in food grain production has been achieved with a large environmental footprint leading to degradation of soil, water, air, and biodiversity. The agronomic productivity so that some of the marginal lands can be set aside for nature conservancy through "Sustainable Intensification" (Lal, 2016).

Yet, there should be no additional allocation of land, water, and other resources. The objective is to produce more from less through adoption of site-specific BMPs which increase agronomic production but without adverse environmental impact and without increasing the land area, water withdrawal or input of fertilizers and pesticides. The approach is focused on the ends rather than the means, and does not pre-determine the technical package.

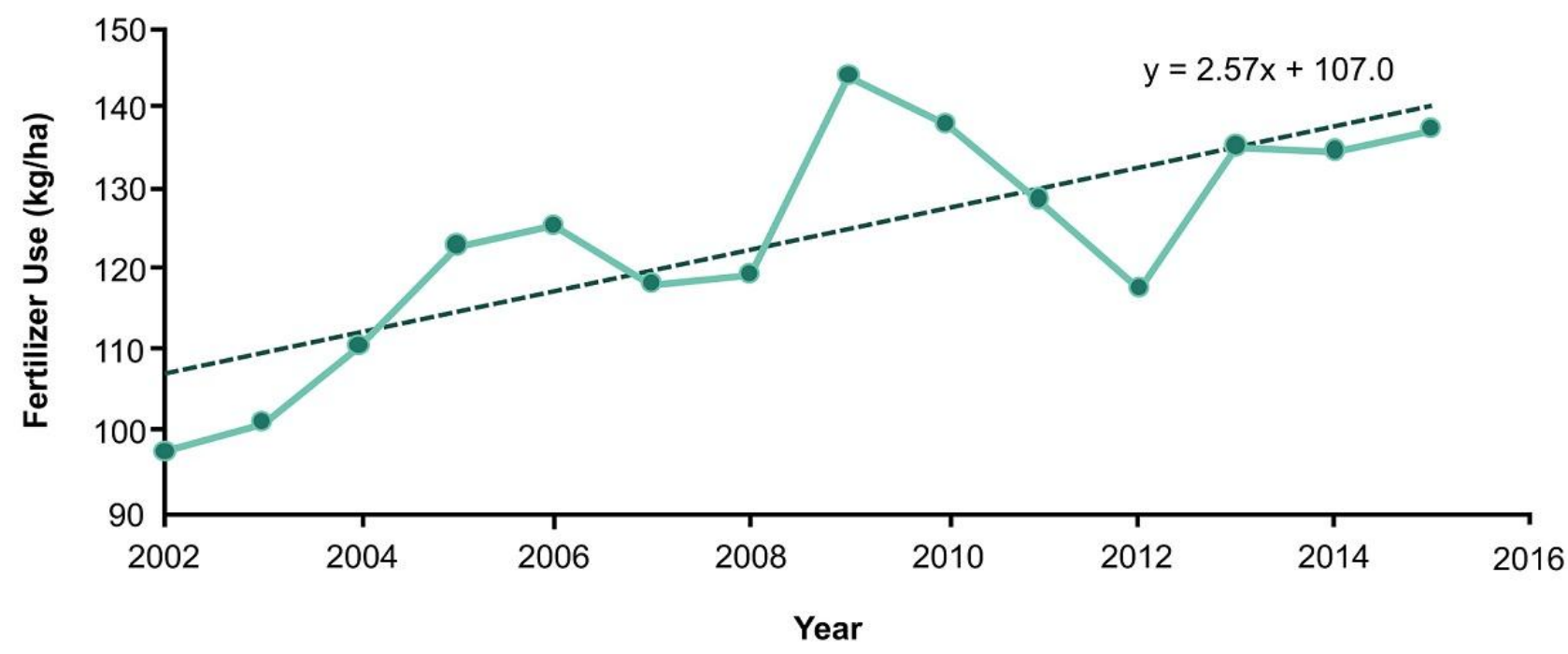

Figure 2: Fertilizer use in Pakistan (kg/ha) between 2002 and 2015 (redrawn from World Bank, 2018)

indiscriminate use of fertilizers, excessive withdrawal of water for flood irrigation, and burning of crop residues (rice straw to facilitate sowing of wheat) have adversely affected the quality of natural resources along with that on human health. There are strong positive effects of irrigation water conservation on crop production and environments, especially in the semi-arid regions (Sarwar and Bastiaanssen, 2001). The challenge lies in reconciling the need for increasing food production with that of restoring the environment quality. It is this challenge that must be the highest priority of scientific community.

Food security in Pakistan, and elsewhere in the developing countries, can be met as follows: (i) reduce food waste, which is now 30 to $50 \%$, by decreasing the post-harvest losses, (ii) increase access to food by reducing poverty, and increasing distribution, (iii) increase in the use of plant-based diet especially of the pulses, (iv) restore soil health by adopting the concept of soil degradation neutrality and the " 4 per Thousand" for sequestration of SOC content, and (v) increase
The concept of "Sustainable Intensification" would involve support of the rural communities, civic societies and of the policymakers. It would also involve some sacrifices as follows: (i) eliminate the in-field biomass burning of crop residues, which must be recycled in the field as mulch, (ii) include forages/cover crops in the rotation cycles, (iii) promote the use of a clean cooking fuel so that cattle dung can be used as manure, (iv) replace flooding with micro-irrigation based on a drip sub-irrigation and fertigation system, (v) discourage use of topsoil for brick making and identify specific locations where clay can be mined to deeper depths, and use other materials (e.g., fly ash, rice husk), and (vi) enhance eco-efficiency of fertilizer $(25 \%$ now to $75 \%)$ and of water ( $30 \%$ now to $90 \%)$

Sustainable management of soil must consider the following principles: (i) replace nutrients and SOM removed, (ii) respond wisely to whatever is changed, and (iii) anticipate what may happen because of anthropogenic and natural perturbations. 


\section{Conclusions}

- Tremendous progress has been made in Pakistan towards improving agricultural production. The rate of increase in food production has been more than that of increase in population,

- Increase in food production has been achieved with the use of improved varieties, expansion in land area equipped for irrigation, and increase in the rate of fertilizer use,

- There has been severe problems of soil degradation (erosion, salinization, depletion of SOC and nutrients, decline in soil structure), depletion of groundwater, and pollution of air because of the in-field burning of crop residues,

- The food availability may have to be doubled between 2015 and 2050 to meet the demands of growing and increasingly affluent population,

- The challenge lies in reconciling the need to enhance agricultural production while restoring soil, recharging aquifers, improving the quality of air, and enhancing biodiversity,

- Identification and adoption of BMPs of sustainable intensification (i.e., conservation agriculture, mulch farming, drip sub-irrigation, cover cropping, no in-field burning, and integrated nutrient management),

- Involving communities, civic societies and policymakers in promoting BMPs,

- Revising curricula from primary/secondary school onward regarding the stewardship of soil and other natural resources, and

- Enhancing the awareness about the need for protection of soil, water and the environment though involvement of the media (newspapers, radio programs, television show, dramas, etc.)

\section{References}

Abbas, A., S. Khan, L. Oxley and D. Kulasiri. 2007. Using remote sensing techniques for appraisal of irrigated soil salinity. Modsim 2007: International Congress on Modelling and Simulation: 2632-2638.

Ahmad, S., A. Ghafoor, M.E. Akhtar, and M.Z. Khan. 2015. Implications of gypsum rates to optimize hydraulic conductivity for variable-texture saline-sodic soil reclamation. Land Degradation \& Development 27:550-560.

Ahmad, S., M. Islam and S. Mirza. 2012. Rangeland degradation and management approaches in balochistan, pakistan. Pakistan Journal of Botany 44:127-136.

Ali, M., W. Ahmad, S. Malhi, B. Atta, A. Ghafoor and M. Zia. 2013. Potential of carbon dioxide biosequestration of saline-sodic soils during amelioration under ricewheat land use. Communications in Soil Science and Plant Analysis 44, no 17:2625-2635.

Ali, S., R. Hayat, F. Begum, B. Bohannan, L. Inebert and K. Meyer. 2017. Variation in soil physical, chemical and microbial parameters under different land uses in Bagrot valley, Gilgit, Pakistan. Journal of the Chemical Society of Pakistan 39, no 1:97-107.

Allen, R., E. Bridges, I. Hannam, L. Oldeman, W. Devries, S. Scherr and S. Sombatpanit. 2001. Strategies to address land degradation issues in the Hindu KushHimalayas. Response To Land Degradation: 304-313.

Anjum, S., L. Wang, L. Xue, M. Saleem, G. Wang and C. Zou. 2010. Desertification in pakistan: Causes, impacts and management. Journal of Food Agriculture \& Environment 8, no 2:1203-1208.

Chambers, A., R. Lal, K. Paustian. 2016. Soil carbon sequestration potential of US croplands and grasslands: Implementing the 4 per Thousand Initiative. Journal of Soil and Water Conservation 71(3):68A-76A.

Condom, N., M. Kuper, S. Marlet, V. Valles and J. Kijne. 1999. Salinization, alkalinization and sodification in punjab (pakistan): Characterization of the geochemical and physical processes of degradation. Land Degradation \& Development 10, no 2:123-140.

Conningham, R. and R. Young. 2015. Archaeology of South Asia: From Indus to Asoka, C6500-200CE. Cambridge University Press, Cambridge, U.K., 556 pp.

Corbishley, J. and D. Pearce. 2007. Growing trees on saltaffected lands. ACIAR Impact Assessment Series Report \#51, July 2007, Canberra, Austalia.

Cowie, A., B. Orr, V. Sanchez, P. Chasek, N. Crossman, A. Erlewein, G. Louwagie, M. Maron, G. Metternicht, S. Minelli, A. Tengberg, S. Walter and S. Welton. 2018. Land in balance: The scientific conceptual framework for land degradation neutrality. Environmental Science \& Policy 79:25-35.

Daily Times. 2016. 20\% of Pakistan's land affected by erosion. Publish online $19^{\text {th }}$ November 2016, https://dailytimes.com.pk/45211/20-of-pakistans-landaffected-by-erosion/

FAO. 1994. Land degradation in South Asia: its Severity, Causes and Effects Upon the People. Food and Agriculture Organization of the United Nations, Rome, Italy.

FAO. 2018. Statistical database. Rome, Italy. Accessed 21 February 2018.

Glover, H. 1941. Erosion in the Punjab: its causes and cure. Review by H.H. Bennett. Geographical Review 36(3):519-520.

Gul, B., M. Islam, S. Ahmad and S. Gul. 2016. Aboveground biomass and concentration of nutrients in semiarid rangeland plant species: Influence of grazing 
and soil moisture. Phyton-International Journal of Experimental Botany 85:94-99.

Howard, A. 1925. The effect of grass on trees. Proceedings of the Royal Society B 97:284-321.

Howard, A., G.L.C. Howard. 1929. The development of Indian agriculture. India of Today, VII ( $2^{\text {nd }}$ Edition), Humphrey Milford and Oxford University Press.

Iqbal, F. 2011. Detection of salt affected soil in rice-wheat area using satellite image. African Journal of Agricultural Research 6, no 21:4973-4982.

Iqbal, M., H. Van Es, Anwar-Ul-Hassan, R. Schindelbeck and B. Moebius-Clune. 2014. Soil health indicators as affected by long-term application of farm manure and cropping patterns under semi-arid climates. International Journal of Agriculture and Biology 16, no 2:242-250.

Irshad, M., M. Inoue, M. Ashraf, Z. Ahmad and Faridullah. 2007. The mitigation challenge of salt affected soils in pakistan. Journal of Food Agriculture \& Environment 5, no 2:280-283.

Kenoyer, J.M. 1991. The Indus Valley tradition of Pakistan and western India. Journal of World Prehistory 5:1-64.

Khan, A., A. Ali, F. Attaurrahman and R. Shaw. 2015. Desertification risk reduction approaches in pakistan. Disaster Risk Reduction Approaches in Pakistan: 161-173.

Khan, M.A., Ahmad, M., H.S. Hashmi. 2012. Review of available knowledge on land degradation in Pakistan. OASIS Country Report 3, ICARDA, Aleppo, Syria.

Khan, N., V. Rastoskuev, Y. Sato and S. Shiozawa. 2005. Assessment of hydrosaline land degradation by using a simple approach of remote sensing indicators. Agricultural Water Management 77, no 13:96-109.

Khan, S., J. Nair, C. Furedy, C. Hoysala and H. Doelle. 2009. Rehabilitation of degraded ecosystems in drylands of southern pakistan: Community-led innovative interventions for getting optimum bioproduction from wastelands. Technologies and Management For Sustainable Biosystems: 131-144.

Lal, R. 2014. Societal value of soil carbon. Journal of Soil and Water Conservation 69:186A-192A.

Lal, R. 2016. Beyond COP21: Potential and challenges of the "4 per Thousand" initiative. Journal of Soil and Water Conservation 71:20A-25A.

Lal, R. 2018. Promoting "4 Per Thousand" and "Adapting African Agriculture" by south-south cooperation: Conservation agriculture and sustainable intensification. Soil and Tillage Research (In press).

Loveland, P.J., and J. Webb. 2003. Is there a critical level of organic matter in the agricultural soils of temperate regions: a review. Soil and Tillage Research 70:1-18.
Mian, A., and Y. Javed. 1989. The soil resources of Pakistan: their potential, present state and strategies for conservation. Sector Paper of the National Conservation Strategies. Soil Survey of Pakistan, Lahore, $53 \mathrm{pp}$.

Minasny, B., B.P. Malone, A.B. McBratney, D.A. Angers, D. Arrouays, A. Chambers, V. Chaplot, Z.S. Chen, K. Cheng, B.S. Das, D.J. Field, A. Gimona, C.B. Hedley, S. Young-Hong, B. Mandal, B.O. Matchant, M. Martin, B.G. McConkey, V.L. Mulder, S. O’Rourke, A.C. Richer-de-Forges, I. Odeh, J. Padarian, K. Paustian, G. Pan, L. Poggio, I. Savin, V. Stolbovoy, U. Stockmann, Y. Sullaeman, C.C. Tsui, T.G. Vågen, B. van Wesemael, L. Winowiecki. 2017. Soil carbon 4 per mille. Geoderma 292:59-86

Qasim, S., R. Shrestha, G. Shivakoti and N. Tripathi. 2011. Socio-economic determinants of land degradation in pishin sub-basin, pakistan. International Journal of Sustainable Development and World Ecology 18, no 1:48-54.

Qasim, S., S. Gul, M. Shah, F. Hussain, S. Ahmad, M. Islam, G. Rehman, M. Yaqoob and S. Shah. 2017. Influence of grazing exclosure on vegetation biomass and soil quality. International Soil and Water Conservation Research 5, no 1:62-68.

Qiu, L., M. Koondhar, Y. Liu and W. Zeng. 2017. Land degradation is the instinctive source of poverty in rural areas of pakistan. 2017 International Conference on Sustainable Development on Energy and Environment Protection 86.

Qureshi, A., M. Asghar, S. Ahmad and I. Masih. 2004. Sustaining crop production in saline groundwater areas: A case study from pakistani punjab. Australian Journal of Agricultural Research 55, no 4:421-431.

Rasul, F., A. Ahmad, M. Arif, I. Mian, K. Ali, M. Qayyum, Q. Hussain, M. Aon, S. Latif, R. Sakrabani, M. Saghir, G. Pan, S. Shackley and E. Lichtfouse. 2017. Biochar for agriculture in pakistan. Sustainable Agriculture Reviews 22:57-114.

Sarwar, A. and W. Bastiaanssen. 2001. Long-term effects of irrigation water conservation on crop production and environment in semiarid areas. Journal of Irrigation and Drainage Engineering-Asce 127, no 6:331-338.

Shafqat, U., A. Nasir, S. Shah, M. Saeed and M. Farid. 2016. Experimental and modeling approach for soil physical degradation due to different irrigation techniques. Pakistan Journal of Agricultural Sciences 53, no 2:481-U49.

Shah, Z. and M. Arshad. 2006. Land degradation in Pakistan: a serious threat to environments and economic sustainability. Retrieved from http://www.eco-web.com/edi/060715.html 
Tariq, S.Z., M.M.B. Baig, and M. Aslam. 2004. Land and environmental degradation and its amelioration for sustainable agriculture in Pakistan. Science Vision 9(12): $1-5$.

UN. 2014. World urbanization prospects. The Department of Economic and Social Affairs. New York, USA, 493 pp.

UN. 2017. World population prospects: key findings and advance tables, 2017 revision. UN, New York, USA, 46pp.

Van Lynden, G.W.T. and J.R. Oldeman. 1997. The assessment of the status of human-induced soil degradation in south and southeast Asia. ISRIC, Wageningen, $35 \mathrm{pp}$.
World Bank. 2018. Fertilizer use in Pakistan. Database, Washington, D.C.

Zokaib, S. and G. Naser. 2011. Impacts of land uses on runoff and soil erosion a case study in Hilkot watershed Pakistan. International Journal of Sediment Research 26, no 3:343-352.

Zulfiqar, F. and G. Thapa. 2017. Agricultural sustainability assessment at provincial level in Pakistan. Land Use Policy 68:492-502. 